\title{
TINJAUAN YURIDIS PERTANGGUNGJAWABAN PIDANA TERHADAP UJARAN KEBENCIAN (HATE SPEECH) DI MEDIA SOSIAL
}

\author{
I Made Andy Sabda Permana, Anak Agung Sagung Laksmi Dewi, Ni Made Sukaryati Karma \\ Fakultas Hukum, Universitas Warmadewa, Denpasar-Bali, Indonesia \\ otupegeneziz39@gmail.com, laksmiidewi29@gmail.com, sukariati64@gmail.com
}

\begin{abstract}
Abstrak
Kebebasan berpendapat yang tidak terbatas menyebabkan kejahatan ujaran kebencian semakin banyak terjadi di masyarakat khususnya di media sosial, apalagi terkait dengan kejahatan ini masih belum ada peraturan khusus sebagai regulasi dalam meminimalisir kasus seperti ini. Tujuan penelitian ini untuk mengkaji pengaturan hukum tindak pidana ujaran kebencian melalui media sosial serta pertanggungjawaban pidana ujaran ujaran kebencian melalui media sosial. Penelitian ini menggunakan hukum normatif melalui pendekatan perundang-undangan dan konseptual dengan didasarkan pada bahan hukum primer dan sekunder dengan studi dokumen, kemudian hasilnya disajikan secara deskriptif analisis. Hasil penelitian menunjukkan bahwa dasar atas pelanggaran hukum bagi pihak yang melakukan ujaran kebencian di media sosial didasarkan pada Undang-undang Nomor 11 Tahun 2008 tentang ITE dan Undang-undang Nomor 19 Tahun 2016 atas perubahan Undang-undang Nomor 11 Tahun 2008. Sesuai dengan pengaturan hukum tersebut maka pertanggungjawaban kejahatan ujaran kebencian di media sosial diatur dalam Pasal 45A ayat (2) Undang-undang Nomor 19 Tahun 2016 yaitu akan diberikan pidana penjara paling lama 6 tahun dan/atau di denda paling banyak 1.000.000.000,00 (Satu Miliar Rupiah).

Kata Kunci: Media Sosial, Pertanggungjawaban Pidana, Ujaran Kebencian
\end{abstract}

\begin{abstract}
Unlimited freedom of expression causes hate speech crimes to occur more and more in society, especially on social media, especially related to this crime, there is still no special regulation as a regulation in minimizing cases like this. The purposes of this study are to examine the legal regulation of hate speech crimes through social media and criminal liability for hate speech through social media. This study uses normative law through a statutory and conceptual approach based on primary and secondary legal materials with document studies, then the results are presented in a descriptive analysis. The results of the study show that the basis for violating the law for those who make hate speech on social media is based on Law No. 11 of 2008 concerning ITE and Law No. 19 of 2016 on amendments to Law No. 11 of 2008. In accordance with legal regulations Therefore, the responsibility for hate speech crimes on social media is regulated in Article 45A paragraph (2) of Law Number 19 of 2016 which will be given a maximum imprisonment of 6 years and/or a maximum fine of 1,000,000,000.00 (One Billion Rupiah).
\end{abstract}

Keywords: Social Media, Criminal Liability, Hate Speech

\section{PENDAHULUAN}

Negara Indonesia dikenal sebagai salah satu negara demokrasi yang secara tertulis dan non tertulis yang dijamin oleh konstitusi dan negara. Kemerdekaan mengemukakan pendapat tidak memiliki tekanan oleh pihak manapun dan dijamin keberadaannya oleh hukum yang berlaku (MD, 2003). Hal tersebut diatur oleh Undang-undang Dasar Negara Republik Indonesia Tahun 1945. Setiap individu memiliki hak dasar yang tercantum dalam konstitusinya. Di Indonesia, kebebasan untuk berpendapat diatur dalam Pasal 28E ayat (3). Di samping itu, dalam ketentuan pasal 28F UUD NRI 1945 yang berbunyi Setiap orang berhak untuk berkomunikasi dan memperoleh informasi untuk mengembangkan pribadi dan lingkungan sosialnya, serta berhak untuk mencari, memperoleh, memiliki, menyimpan, mengolah, dan menyampaikan informasi dengan menggunakan segala jenis saluran yang tersedia.

Seseorang dalam mengeluarkan pendapatnya dihargai orang lain meskipun dalam implementasinya harus tetap tunduk terhadap peraturan yang ada. Sesuai dengan pernyataan tersebut telah disebutkan dalam Pasal 28J ayat (2) UUD NKRI 1945 yaitu dalam menjalankan hak dan kebebasannya, setiap orang wajib tunduk kepada pembatasan yang ditetapkan dengan undangundang dengan maksud semata-mata untuk menjamin pengakuan serta penghormatan atas hak dan 
kebebasan orang lain dan untuk memenuhi tuntutan yang adil sesuai dengan pertimbangan moral, nilai-nilai agama, keamanan, dan ketertiban umum dalam suatu masyarakat demokratis. Lebih lanjut, Pasal 1 ayat (1) Undang-undang Nomor 9 Tahun 1998 kembali menyebutkan mengenai adanya kebebasan untuk menyampaikan aspirasi oleh masyarakat. Dalam peraturan ini dinyatakan bahwa setiap individu berhak untuk menyampaikan perasaannya baik secara lisan dan non lisan tidak bertentangan dengan konstitusi hukum yang mengaturnya. Berdasarkan uraian tersebut maka dapat dilihat terjadi kekaburan norma, dimana belum terdapat Pasal yang jelas yang mengatur ujaran kebencian melalui media sosial.

Perkembangan teknologi beberapa dekade terakhir ini semakin menyebabkan gejolak dalam hukum, terutama dalam hal penyampaian pendapat. Adanya kekaburan norma dalam memaknai kata kebebasan menjadi boomerang bagi pelaksana konstitusi di Indonesia. Keberadaan alat-alat teknologi dan komunikasi yang semakin canggih menyebabkan perubahan manusia akan gaya hidup dan pola pikirnya yang semakin praktis dan menjadi tidak terbatas. Termasuk didalamnya untuk menyampaikan pemikirannya, manusia menjadi merasa tak memiliki batasan, apapun yang dianggap tidak sesuai dengan pemikiran dan perasaannya maka akan dilakukan protes dan tentunya ini tidak sesuai dengan kaidah hukum yang sebenarnya. Keberadaan media sosial menjadi semakin memperkeruh suasana. Ketidakterbatasan akibat tidak adanya batasan menyebabkan kebebasan dalam menyampaikan pendapat semakin tak dapat dibatasi (Suhariyanto, 2014). Perkembangan teknologi dan komunikasi ini pada dasarnya dapat memberikan nilai positif tetapi juga memiliki nilai negatif. Akan diperoleh dampak positif apabila keberadaan teknologi yang semakin canggih dimanfaatkan dengan efektif dan efisien. Tetapi yang menjadi permasalahannya adalah apabila teknologi ini tidak dimanfaatkan secara efisien justru dapat menimbulkan banyak permasalahan dan peningkatan kasus kriminalitas (Sitompul, 2012).

Dalam arti hukum, ujaran kebencian (hate speech) ialah perkataan, perilaku, tulisan, ataupun pertunjukan yang dilarang karena dapat memicu terjadinya tindakan kekerasan dan sikap prasangka entah dari pihak pelaku pernyataan tersebut ataupun korban dari tindakan tersebut (Sya'bana et al., 2021). Ujaran kebencian telah diatur sedemikian rupa dalam Undang-undang Nomor 19 Tahun 2016 tentang Perubahan atas Undang-undang Nomor 11 Tahun 2008 tentang Informasi dan Transaksi Elektronik, pengaturan tersebut termasuk kategori ujaran kebencian dan tindak pidana yang akan diterima oleh pelaku yang terkandung dalam pasal 45 dan pasal 45A (Yana et al., 2021). Kasus ujaran kebencian tidak hanya menjadi permasalahan antar individu saja, tetapi juga sudah menjadi masalah nasional dan juga internasional. Hal ini mengingat bahwa setiap manusia pada saat ini telah dilindungi oleh keberadaan hak asasi manusia dan juga karena semakin meningkatnya perhatian akan kasuskasus yang terjadi di masyarakat. Untuk itu diberlanjutkan Undang-undang Nomor 11 Tahun 2008 tentang ITE, Surat Edaran Nomor SE/06/X/2015 dan Undang-undang Republik Indonesia Nomor 19 Tahun 2016 Tentang Perubahan Atas Undang-undang Nomor 11 Tahun 2008 Tentang Informasi dan Transaksi Elektronik. Bebarapa peraturan telah dikeluarkan tetapi nyatanya belum ada peraturan khusus yang mengatur mengenai tindak pidana ujaran kebencian (hate speech) seperti di negaranegara lain. Untuk itu dalam memastikan terciptanya kepastian, keadilam dan kemanfaatan bagi masyarakat, maka disinlah hukum berperan. Sendi-sendi keadilan akan menimbulkan kepuasan dan penghindaran konflik apabila hukum itu sendiri mampu memberikan nilai kepastian hukum yang jelas (Huijbers, 2011).

Penelitian terdahulu yang relevan dengan penelitian ini mengungkapkan bahwa Tindak pidana ujaran kebencian di Indonesia belum diatur secara khusus dalam suatu peraturan perundangundangan, namun dengan adanya Undang-undang Informasi dan Transaksi Elektronik yang baru yaitu Undang-undang Nomor 11 Tahun 2008 mengakibatkan pertanggungjawaban pidana terhadap tindak pidana ujaran kebencian menjadi lebih memiliki kepastian hukum dan meminimalisir terjadinya multi tafsir serta sudah mengakomodir alat bukti baru untuk pembuktian tindak pidana ujaran kebencian (Hate Speech) (Permatasari \& Sudibya, 2018); (Oktiawan, 2021). Adapun menurut Febriansyah \& Purwinarto (2020) mengungkapkan salah satu faktor terjadinya ujaran kebencian di media sosial terjadi karena mereka belum paham terhadap undang-undang yang ada. Akan tetapi kesalahan maupun kealpaan tetap menjadi tanggung jawab individu sebagai subyek hukum. Dari fenomena tersebut maka ingin dilakukan penelitian yang bertujuan untuk mengkaji pengaturan hukum tindak 
pidana ujaran kebencian melalui media sosial serta pertanggungjawaban pidana ujaran ujaran kebencian melalui media sosial.

\section{METODE PENELITIAN}

Permasalah hukum diselesaikan dengan menggunakan hukum normatif melalui pendekatan perundang-undangan dan konseptual. Untuk memperoleh jawaban atas permasalahan yang dikaji maka akan dilakukan pengumpulan data dengan menggunakan bahan hukum primer dan juga bahan hukum sekunder dengan melakukan penelitian studi kepustakaan. Bahan hukum yang telah diperoleh tersebut kemudian dicatat, dikutip, diringkas dan kemudian melakukan analisis terhadap dokumen baik yang berupa peraturan perundang-undangan, literature, surat kabar internet dan juga klausulklausul lainnya yang sesuai dengan penelitian ini. Selanjutnya keberadaan bahan hukum tersebut akan dideskripsikan dengan menggunakan kata-kata tertulis dan juga lisan dari informan yang berkaitan dengan permasalahan yang akan dibahas dan dapat ditarik kesimpulan atas jawaban permasalahan yang ada dan juga memberikan rekomendasi akhir atas hasil penelitian.

\section{HASIL DAN PEMBAHASAN}

\section{Pengaturan Hukum Tindak Pidana Ujaran Kebencian Melalui Media Sosial}

Dalam pengertian hukum ujaran kebencian (Hate Speech) terkait dengan kasus yang terjadi dari perkataan, perilaku, tulisan maupun perbuatan yang melanggar aturan yang menimbulkan huru-hara dalam kehidupan masyarakat. Setiap masyarakat yang melakukan tindak pidana kebencian tak akan dapat diampuni. Pengaturan hukum menjadikan setiap masyarakat harus menghormati setiap orang baik secara individu dana tau komunitas. Tidak akan tercipta kasus yang merugikan banyak pihak apabila setiap pihak sadar dan mau menghormati satu sama lainnya. Tindak pidana ini masuk kedalam tindak pidana sesuai dengan yang diatur dalam KUHP dan ketentuan pidana lainnya diluar KUHP, seperti adanya kasus penghinaan, pencemaran nama baik, kasus penistaan, perbuatan tidak menyenangkan, mempersuasikan orang atau kelompok, menghasut dan menyebarkan hoax. Tindak pidana dapat menyebabkan akibat yang sangat membahayakan, bahkan hingga pengilangan nyawa sesorang, kekeringan, diskriminasi dan juga menimbulkan perselisihan ini tentunya adalah negatif yaitu untuk menghasut sesorang atau menyulut kebencian terhadap individu dan atau kelompok masyarakat dalam berbagai komunitas.

Terkait dengan beberapa peraturan yang mengatur penegakan hukum atas ujaran kebencian mengacu kepada beberapa peraturan yaitu

1. Pasal 156 KUHP, Pasal 157 ayat (1) dan ayat (2) KUHP, Pasal 310 ayat (1), (2), dan (3) KUHP serta Pasal 311 KUHP ayat (1).

2. Pasal 28 ayat (1) dan (2) Undang-Undang Nomor 11 Tahun 2008 tentang ITE.

3. Pasal 45 ayat (3), Pasal 45A ayat (1) dan ayat (2) Undang-Undang Nomor 19 Tahun 2016 Tentang Perubahan Atas Undang-Undang Nomor 11 Tahun 2008 Tentang ITE.

4. Pasal 16 atas Undang-Undang Nomor 40 Tahun 2008 tentang Penghapusan Diskriminasi Ras dan Etnis.

5. Didalam Surat Edaran Kapolri NOMOR SE/06/X/2015 tentang Ujaran Kebencian (Hate Speech).

Pasal 28 Undang-undang Dasar Negara Republik Indonesia Tahun 1945 mengatur mengenai kekebalan dalam penyampaian pendapat. Tetapi kebebasan yang dimaksudkan dalam pasal ini seringkali menimbulkan multitafsir dan menyebabkan banyak masyarakat yang menyalahgunakan kata kebebasan yang dituliskan. Kebebasan untuk menyampaikan pendapat di muka umum justru menyebabkan timbulnya kasus yang menjadi perkara bagi pihak yang melakukan kesalahan. Tindak pidana ini dapat membahayakan jiwa baik secara fsikis maupun psikologis seseorang. Untuk itu maka tindak pidana ujaran kebencian (Hate Speech) ditindak tegas sesuai dengan peraturan yang berlaku. Sebelum ditindak maka akan dilakukan penyelidikan untuk mengumpulkan bukti terkait dengan kasus-kasus ujaran kebencian (Hate Speech). Alat bukti merupakan sarana yang penting untuk menunjukan peristiwa yang sah terjadi. Alat bukti dapat berupa dokumen digital ataupun juga dapat berupa pernyataan dari saksi ahli. Keberadaan alat bukti yang sah dapat menjadi sarana untuk mengajukan tuntutan terhadap kesalahan yang dilakukan oleh pihak yang melakukan pelanggaran. Mengetahui bahwa ada dua alat bukti yang sah tidak cukup bagi hakim untuk menjatuhkan hukuman 
pada seseorang. Namun dari pembuktian yang sah, hakim juga perlu mendapatkan keyakinan bahwa perbuatan salah adalah perbuatan salah.

Pada Undang-undang ITE, tersebut dalam Pasal 42 disebutkan bahwa dasar utama yang digunakan ketika ingin melakukan penyelidikan adalah berpedoman kepada aturan dalam Kitab Undang-undang Hukum Acara Pidana (KUHAP). Adapun yang termasuk ke dalam alat bukti sesuai yang tersurat dalam Pasal 184 KUHAP terdiri atas keterangan saksi, keterangan ahli, surat, petunjuk dan keterangan terdakwa. Alat bukti ini nantinya akan dijadikan sebagai sarana untuk melakukan pembelaan bagi korban. Dalam kasus tindak pidana setiap orang harus berhati-hati karena setiap bukti tidak akan dapat terelakkan terlebih bukti elektronik yang selalu akan meninggalkan jejak digital. Mengenai hal ini seyogyanya setiap individu harus berhati-hati dalam memposting atau membagikan tautan yang berbau penghasutan untuk menghindari terjadinya kasus ujaran kebencian (hate speech). Untuk ujaran kebencian melalui media sosial didasarkan pada Pasal 184 KUHP dan Undang-Undang ITE tersurat dalam Pasal 5 ayat (1), maka alat bukti yang dimaksudkan adalah terdiri atas dua hal yaitu informasi elektronik dan hasil cetak informasi dokumen elektronik. Lebih lanjut dalam Pasal 5 ayat (2) Undang-Undang ITE dijelaskan bahwa merupakan perluasan dari alat bukti yang sah sesuai dengan hukum acara yang berlaku di Indonesia. Alat bukti yang ada akan menjadi pemberatan bagi pihak yang melakukan pelanggaran. Keberadaan Undang-undang ITE menjadi sarana bagi masyarakat untuk selalu waspada dan lebih hati-hati dalam menggunakan media sosial yang dimiliki. Seharusnya masyarakat tidak seenaknya menyampaikan pendapatnya di depan umum. Ada batasan untuk kebebasan yang disampaikan. Masyarakat harus cerdas dan cermat dalam menggunakan kebebasan yang dimiliki. Kebebasan menyampaikan pendapat tidak harus selalu disampaikan dengan terbuka tanpa memikirkan perasaan orang lain. Kasus ujaran kebencian marak terjadi di masyarakat. Hal ini tentunya dapat menimbulkan kerugian bagi masyarakat. Kejelasan norma dan aturan akan membuat masyarakat menjadi lebih hati-hati dalam membuat keputusan. Keleluasaan dalam berbicara dan berperilaku tidaklah menjadikan seseorang untuk tidak menjaga dan memperhatikan kesehatan masyarakat. Tanpa adanya kesadaran diri tindak pidana akan semakin banyak terjadi dan akan merugikan berbagai pihak yang ada di dalamnya.

\section{Pertanggungjawaban Pidana Ujaran Ujaran Kebencian Melalui Media Sosial}

Hukum menyebabkan setiap orang memiliki tanggung jawabnya terhadap kesalahan atau pelanggaran yang dilakukan. Salah satu kasus tindak pidana yang akhir-akhir ini marak mendapat perhatian public adalah kasus Ujaran Kebencian (Hate Speech). Kasus ini dapat menimbulkan pertanggungjawaban hukum terhadap yang melakukan pelanggaran hukum (Huda, 2011). Bentuk pertanggungjawaban atas tindak pidana penghasutan atau ujaran kebencian dituliskan di Pasal 28 ayat (2) yang berbunyi Setiap orang dengan sengaja dan tanpa hak menyebarkan informasi yang ditujukan untuk menimbulkan rasa kebencian atau permusuhan individu dan/atau kelompok masyarakat tertentu berdasarkan atas suku, agama, ras dan antargolongan (SARA). Pasal 45A ayat (2) Undang-undang Republik Indonesia Nomor 19 Tahun 2016 Tentang Perubahan Atas Undang-Undang Nomor 11 Tahun 2008 Tentang Informasi dan Transaksi Elektronik yang menyatakan bahwa setiap orang yang memenuhi unsur sebagaimana dimaksud dalam Pasal 28 ayat (1) dan ayat (2) dipidana dengan pidana penjara paling lama 6 (enam) tahun dan/atau denda paling banyak 1.000.000.000,00 (satu miliar rupiah).

Dari peraturan yang ada telah tertulis dengan jelas mengenai pertanggungjawaban pidana bagi pihak yang melakukan pelanggaran terhadap Undang-undang ITE. Penyampaian pendapat yang bebas tidak boleh melebihi batas-batas kemanusiaan. Hal ini mengingat setiap manusia dilindungi dan memiliki hak asasinya masing-masing. Seyogyanya setiap individu mau dan mampu untuk menghormati individu lainnya. Rasa saling menghargai dan menghormati dapat menjadi tolak ukur untuk mengurangi terciptanya harak dan konflik antar masyarakat, baik itu konflik individu ataupun antar komunitas. Apabila setiap individu dapat hidup dengan rukun dan harmonis maka tindak pidana ujaran kebencian dapat dihindari.

\section{SIMPULAN DAN SARAN}

\section{Simpulan}

Kesimpulan yang dapat diambil dari hasil analisis terhadap pemsalahan yang diangkat adalah pengaturan yang memuat pertanggungjawaban pidana terhadap pelaku ujaran kebencian diatur dalam 
Pasal 28 ayat (1) dan (2) Undang-undang Nomor 11 Tahun 2008 tentang ITE dan Pasal 45 ayat (3), Pasal 45A ayat (1) dan ayat (2) Undang-undang Republik Indonesia Nomor 19 Tahun 2016 tentang Perubahan Atas Undang-undang Nomor 11 Tahun 2008 tentang Informasi dan Transaksi Elektronik. Alat bukti hukum yang mengatur pertanggungjawaban pidana terhadap pelaku penyimpangan wacana penghinaan menurut pasal 5 UU ITE adalah informasi elektronik dan dokumen elektronik beserta hasil cetakannya merupakan alat bukti tambahan yang sah menurut hukum acara yang berlaku di Indonesia. Tanggung jawab penghinaan pelanggaran melalui media berbasis web menyinggung pengaturan pasal 28 ayat (2). Pasal 45A ayat (2) Undang-undang Republik Indonesia Nomor 19 Tahun 2016 tentang Perubahan Atas Undang-undang Nomor 11 Tahun 2008 tentang Informasi dan Transaksi Elektronik dengan ancaman pidana kurungan paling lama 6 tahun atau berpotensi denda paling banyak Rp. 1.000.000.000,00 (satu miliar rupiah).

\section{Saran}

Bagi pemerintah, agar melakukan optimalisasi pada peraturan terkait dengan pembuktian kasus ujaran kebencian. Tetapi kenyataannya di lapangan menunjukkan bahwa untuk saat ini Indonesia belum memiliki peraturan khusus. Hal ini mengingat bahwa Indonesia adalah negara hukum dan setiap orang akan tunduk pada hukum yang berlaku. Selain itu yang tidak kalah penting adalah perlu adanya sosialisasi dan juga penyuluhan bagi masyarakat agar paham dalam memaknai kebebasan penyampaian pendapat di depan umum. Untuk masyarakat, sebaiknya dapat iuntuk memehami tanggung jawabnya terhadap apa yang dilakukannya, terutama untuk memahami pertanggungjawaban hukum mengenai pertanggungjawaban pidana ketika menghasut atau memprovokasi atau mencemarkan nama baik orang menggunakan media sosial. Masyarakat sebaiknya juga lebih hati-hati dalam menyampaikan pendapatnya dimuka umum utnutk menghinadri sanksi hukum dalam Undangundang ITE. Untuk peneliti selanjutnya, perlu adanya kajian secara empiris untuk menganalisis tindak pidana Hate Speech menggunakan media sosial sehingga akan ditemukan solusi yang lebih riil untuk meminimalisasi kasus pidana ujaran kebencian.

\section{DAFTAR PUSTAKA}

Febriansyah, F. I., \& Purwinarto, H. S. (2020). Pertanggungjawaban Pidana Bagi Pelaku Ujaran Kebencian di Media Sosial. Jurnal Penelitian Hukum De Jure, 20(2), 177-188.

Huda, C. (2011). Dari Tindak Pidana Tanpa Kesalahan Menuju Kepada Tiada Pertanggungjawaban Pidana Tanpa Kesalahan. Kencana, Jakarta.

Huijbers, T. (2011). Filsafat Hukum Dalam Lintasan Sejarah. Kanisius, Yogyakarta.

MD, M. M. (2003). Demokrasi dan Konstitusi di Indonesia. Rineka Cipta, Jakarta.

Oktiawan, C. (2021). Yuridis Tindak Pidana Ujaran Kebencian Dalam Media Sosial. Al-Adl, 3(1), $168-188$.

Permatasari, G. A. M. G., \& Sudibya, K. P. (2018). Tinjauan Yuridis Mengenai Pengaturan dan Pertanggungjawaban Pidana Terhadap Tindak Pidana Ujaran Kebencian di Media Sosial. Kertha Wicara, 7(3), 1-15.

Sitompul, J. (2012). Cyberspace, Cybercrimes, Cyberlaw Tinjauan Aspek Hukum Pidana. Tatanusa, Jakarta.

Suhariyanto, B. (2014). Tindak Pidana Teknologi Informasi (Cybercrime). Raja Grafindo Persada, Jakarta.

Sya'bana, S. A., Marbun, W., \& Krisnalita, L. Y. (2021). Pertanggungjawaban Pidana Pelaku Ujaran Kebencian Melalui Media Elektronik (Studi Kasus Putusan Nomor 370/Pid.Sus/2018/PN.Jkt.Sel). Jurnal Krisna Law, 3(2), 1-13.

Yana, E., Amboroo, F. Y. P., Nurisman, E., \& Hadiyati, N. (2021). The Role of The Polri in The Law Enforcement of The Distribution of Hate Speech in The City of Batam, Indonesia. Ganesha Law Review, 3(1), 43-55. 